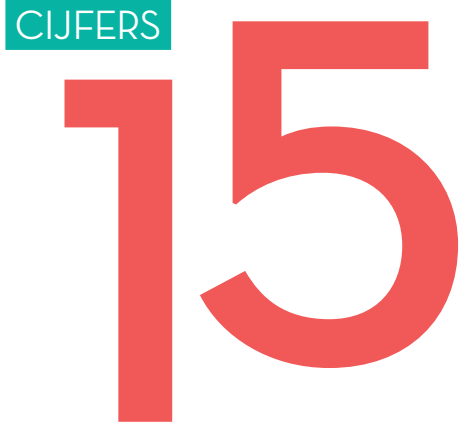

Dit is het percentage strafbeschikkingen dat in 2016 onterecht werd opgelegd door het Openbaar Ministerie, blijkt uit interne rapporten van het OM en onderzoek van $N R C$. Het ontbrak aan bewijs of de onderzoekers konden door incomplete dossiers niet zien of de schuld juist was vastgesteld. Soms bleek een straf voor het verkeerde feit opgelegd.

\section{CITAAT}

\section{'Die beschul-} diging was onnodig diffamerend en onvoldoende gefundeerd

\section{en is later}

\section{ook onjuist gebleken.'}

De Rechtspraak rectificeert op last van de Hoge Raad uitlatingen over advocaat Hugo Smit, gedaan in 2006, in een brief aan de Tweede Kamerfractie van de SP.
COLUMN

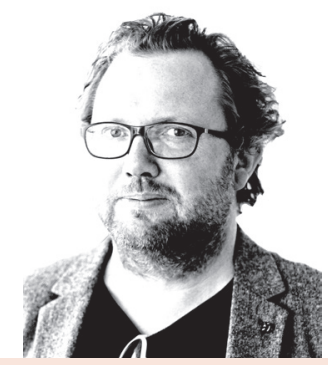

DOOR / HARRY VEENENDAAL

\title{
Weapons of math destruction
}

D e heren van de Britse rockband MUSE waarschuwen in hun track 'algorithm' voor artificiële intelligentie (AI). Bestsellerauteur Cathy O'Neil vindt algoritmische besluitvorming $(\mathrm{AB})$ net zo gevaarlijk als kernwapens. AI/AB leidt tot strijdigheid met de Grondwet en internationaalrechtelijke verdragsbepalingen. Deze angst zal in 2019 en de jaren daarna toenemen, maar wordt schromelijk overdreven.

Nederland loopt voorop in de algoritmische fanfare-van-paniek. Van Eck, Bovens en Zouridis constateren in NJB (40) dat toezicht op besluitvorming van de overheid verschuift naar systeemontwikkelaars, software-engineers en dataprofessionals. Help! De rechtsstaat is in gevaar. Gelukkig denkt ons parlement rustig en evenwichtig na over wetgeving. Bijvoorbeeld over artikel 22 AVG dat regelt dat een persoon niet onderworpen hoeft te zijn aan besluiten louter gebaseerd op AI/AB. Maar hoe dan? Grootschalige AB bij de overheid vindt plaats bij onder meer de Belastingdienst, het UWV en de DUO. In de private sector maken financiële instellingen veelvuldig gebruik van premiedifferentiatie op basis van postcode bij het verstrekken van hypotheken. En de meeste ziekenhuizen in Nederland werken met geavanceerde planningspakketten voor medewerkers en patiënten. Niels Jak en Steven Bastiaans concluderen in NJB (40) dat controleerbaarheid en transparantie de toverwoor- den zijn. Met deze waarborgen moet rechterlijke controle op beslisregels mogelijk gemaakt worden. Van Eck c.s. sluiten aan bij deze gedachte: een steekproefsgewijze audit op algoritmiek door een externe toezichthouder. Deze nieuwe (Europese) toezichthouder moet de rechtmatigheid van beslisregels borgen. Het liefst zien de auteurs een heuse 'AI-autoriteit'.

Het blijven onzinnige standpunten. Een gemiddeld complex planningspakket waarin cao-regels zijn verwerkt kent doorgaans honderdduizenden, zo niet miljoenen programmeerregels. Rechters, OvJ's en andere juridisch welwillenden zijn best kundig, maar doorgaans niet in het interpreteren van complexe algoritmische decision trees. Alleen al bij de gedachte aan al die door rechters aangestelde experts en langdurige procedures krijg ik fantoompijn in mijn portefeuille. Veel eenvoudiger is een vrijwillige escrow-procedure dat geen depot als oogmerk heeft, maar het verlenen van een keurmerk. Vergelijkbaar met een ISO-kwalificatie. Eenmalig wordt een softwarepakket via reverse engineering getest op vooraf gedefinieerde beslisregels. Overheidsinstellingen zouden alleen software moeten aanschaffen met dit keurmerk. De angst voor AI/AB wordt overdreven omdat de menselijke factor onmisbaar blijft. Als het wiel nog niet was uitgevonden, had $\mathrm{AI} / \mathrm{AB}$ het zeker niet gedaan. 